\title{
Assessing a brand equity model for fast moving consumer goods in cosmetic and hygiene industry
}

\author{
Alireza Karbasivar ${ }^{a^{*}}$, Mirahmad Amirshahi ${ }^{\mathrm{b}}$ and Kambiz Heidarzadeh ${ }^{\mathrm{c}}$
}

${ }^{a}$ Ph.D. Student (Marketing Management), Department of Management, School of Management and Economics, Science and Research Branch, Islamic Azad University (IAU), Tehran, Iran

${ }^{b}$ Assistant. Prof. \& Faculty Member, Department of Management, School of Social Science, Alzahara University, Tehran, Iran

${ }^{c}$ Associate. Prof. \& Faculty Member, Department of Management, School of Management and Economics, Science and Research Branch, Islamic Azad University (IAU), Tehran, Iran

\section{H R O N I C L E A B T T A C T}

Article history:

Received June 4, 2014

Accepted 29 September 2014

Available online

October 62014

Aaker Model

Brand Loyalty

Brand awareness

Perceived quality

Brand Association

\begin{abstract}
This paper presents an empirical investigation to study the effects of ten factors on brand equity. The study provides an assessment using a brand equity model for fast moving consumer goods in cosmetic and hygiene industry. The study has accomplished among people who purchase goods in six major cities of Iran based on an adapted questionnaire originally developed by Aaker (1992a) [Aaker, D. A. (1992a). The value of brand equity. Journal of Business Strategy, 13(4), 27-32.]. Cronbach alpha has been calculated as 0.88, which is well above the minimum acceptable level of 0.7. In addition, Kaiser-Meyer-Olkin Measure of Sampling adequacy and Bartlett's test of Sphericity approximation Chi-Square are 0.878, 276628 with Sig. $=0.000$, respectively. The proposed study of this paper uses structural equation modeling to test different hypotheses of the survey. The Root Mean Square Error of Approximation (RMSEA), Comparative Fit Index (CFI) and Chi-Square/df are 0.067, 0.840 and 4.244 and they are within desirable levels. While the effects of seven factors on brand equity have been confirmed. However, the survey does not confirm the effects of perceived value, advertisement effectiveness and advertisement to brand on brand equity. In our survey, brand loyalty maintains the highest positive impact followed by having updated brand, trust to brand, perceived quality to brand, brand awareness, intensity of supply and perception to brand.
\end{abstract}

\section{Introduction}

Brand equity is normally used in the marketing industry to explain the value of having a well-known brand name, based on a basic idea that the owner of a famous brand name may create more money from products and services with that brand name than from products with a less well-known name, as consumers may think that a product with a famous name could be better than products with less wellknown names (Aaker, 1992a, 1992b, 1996, 1997, 2009, 2012; Farquhar, 1989; Grannell, 2009; Keller et al., 2011). Many scholars believe that brands could be considered as the most valuable assets a company has (Netemeyer et al., 2004), as brand equity is one of the factors, which may increase the financial value of a brand to the brand owner, although not the only one (Grannell, 2009). 
There are different associated with the valuation of brand equity such as changing market share, profit margins, etc. Agarwal and Rao (1996) compared eleven consumer-based brand equity measures, evaluated their convergence, predictive validity at the individual and aggregate levels. Aggarwal (2004) studied the effects of brand relationship norms on consumer attitudes and behavior. Ambler et al. (2004) investigated the metrics that companies choose and some reasons for those choices based on some data extracted from two UK studies. The first one investigated practitioner usage by the main metrics categories including consumer behavior and intermediate, trade customer, competitor, accounting and innovativeness while the second one studied which individual metrics were the most important. They reported some consistency between orientation and metrics. In addition, they detected 19 metrics, which could be stated as primary and could therefore serve for initial selection. Nevertheless, the sector importantly moderated that selection, not least because competitive benchmarking needed similar metrics to be available. Control, orientation and institutional theories, in their survey, seemed to impact metrics selection and the absence of agency theory was due to the research method. They also concluded with some propositions formally to test the basis of metrics selection.

Ambler and Styles (1997) considered the managerial processes, which could lead to the launch of successful line and brand extensions and concluded that extension decisions were more about brand development than new product development. Anselmsson et al. (2007) developed a framework to understand more about customer-based brand equity and price premium for grocery products. They reported that brand equity and price premium concentrating on the grocery sector specifically could highlight the role of uniqueness, together with the four traditionally basic dimensions of brand equity proposed such as awareness, qualities, associations and loyalty. Atilgan et al. (2005) examined the practicality and application of a customer-based brand equity model, based on Aaker's well-known conceptual framework of brand equity.

Atilgan et al. (2009) reported that the brand equity for global brands could be measured under different dimensions such as perceived quality, brand loyalty, brand associations, and brand trust. According to Baldauf et al. (2003), the consequences of brand equity management is one of the most essential measurement issues for intangible assets in the new economy. Many studies have confirmed the impact of brand equity on the value of the business unit and investigated the capital market impacts of intangible associations such as brand value. Nevertheless, there is not enough evidence on which dimensions of brand equity could be measured and monitored to provide some support on financial performance.

Baldauf et al. (2003) applied regression analysis on a sample of managers in Austrian firms and studied the impact of perceived brand equity on brand profitability, brand sales volume, and perceived customer value. Their surveyed results provided some strong support for measures of perceived quality, brand loyalty, and brand awareness as antecedents of business performance, customer value and willingness to buy. Chaudhuri and Holbrook (2001) investigated two perspectives of brand loyalty, purchase loyalty and attitudinal loyalty, as linking variables in the chain of impacts from brand trust and brand affect on brand performance. They reported that when the product- and brand-level variables were controlled for, brand trust and brand affect could combine to determine purchase loyalty and attitudinal loyalty. Purchase loyalty, in turn, leads to bigger market share, and attitudinal loyalty leads to a higher relative price for the brand.

Fernández-Barcala and González-Díaz (2006) built a linkage between both marketing and transaction cost economics (TCE) literature to describe factors describing brand equity from the buyer's perspective. They argued that TCE could offer an appropriate framework for learning the value added by each brand name and claimed that brand names were more valuable by buyers when contractual hazards in the transaction were higher. Results from an exploratory analysis of $14 \mathrm{EU}$ fruit and vegetable brand names stated that the price premium would be bigger when the brand name addresses less informed parties and when search/measurement costs were substantial. In addition, consumers 
seem ready to spend a higher price premium for co-branded products. They considered this as an indicator that each brand name was specialized in guaranteeing various attributes and that they could complement each other.

Gil et al. (1992) analyzed the role played by the family on consumer-based brand equity. In their survey, information of a brand provided by both the family and the firm was analyzed as a source of consumer-based brand equity and its dimensions. According to Lassar et al. (1995) and Motameni and Shahrokhi (1998), brand equity plays essential role to marketers of consumer goods and services. Brand equity may facilitate in the effectiveness of brand extensions and brand introductions because consumers who trust and display loyalty toward a brand may be more willing to attempt to adopt brand extensions.

Netemeyer et al. (2004) presented some studies, which develop measures of "core/primary" facets of customer-based brand equity (CBBE). They reported that perceived quality, perceived value for the cost, and brand uniqueness were potential direct antecedents of the willingness to spend a price premium for a brand, and that willingness to spend a price premium was a potential direct antecedent of brand purchase behavior.

Yoo et al. (2000) explored the relationships between selected marketing mix elements and the creation of brand equity. They proposed a conceptual framework in which marketing elements were associated with the dimensions of brand equity, which are, perceived quality, brand loyalty, and brand associations combined with brand awareness. These dimensions were then associated with brand equity. They reported that frequent price promotions, such as price deals, were associated with low brand equity, whereas high advertising spending, high price, good store image, and high distribution intensity were associated with high brand equity.

\section{The proposed study}

This paper presents an empirical investigation to determine important factors influencing on brand equity. The study provides an assessment using a brand equity model for fast moving consumer goods in cosmetic and hygiene industry. There are ten hypotheses associated with the proposed study of this paper as follows,

1. Brand loyalty is one of key components of brand equity.

2. Perception to brand is one of key components of brand equity.

3. Brand awareness is one of key components of brand equity.

4. Perceived quality to brand is one of key components of brand equity.

5. Advertisement effectiveness for brand is one of key components of brand equity.

6. Effectiveness of brand advertisement is one of key components of brand equity.

7. Trust to brand is one of key components of brand equity.

8. Having an updated brand is one of the key components of brand equity.

9. Brand features are key components of brand equity.

10. Intensity of supply is one of the key components of brand equity.

The structure of this study has been adopted from the existing literature (Aaker, 1992a, 1992b, 1996, 1997, 2009, 2012). The proposed study designs a questionnaire in Likert scale, which consists of 
various questions. Table 1 demonstrates the summary of the descriptions of all categories as well as the number of questions assigned to each item.

\section{Table 1}

The summary of different categories and the number of questions

\begin{tabular}{cccc}
\hline Question & Description & Question & Description \\
\hline 10 & Being updated brand & 7 & Quality of brand \\
9 & Easy remembrance & 6 & Continues purchase of brand \\
8 & Meeting customers' needs & 5 & Weak price elasticity to brand \\
7 & Trust to quality & 4 & Paying no attention to price \\
9 & purchase of brand Permanent & 9 & Availability of brand \\
10 & Availability of brand in all stores & 8 & Recommendation to others \\
\hline
\end{tabular}

The study has accomplished in major of Iranian cities; namely Tehran, Karaj, Mashhad, Ahvaz, Esfahan and Tabriz. The sample size is calculated as follows,

$$
N=Z_{\alpha / 2}^{2} \frac{p \times q}{e^{2}},
$$

where $N$ is the sample size, $p=1-q$ represents the probability, $Z_{\alpha / 2}$ is CDF of normal distribution and finally $\varepsilon$ is the error term. For our study we assume $p=0.5, Z_{\alpha / 2}=1.96$ and $e=0.05$, the number of sample size is calculated as $N=716$. In our study, we have managed to distribute 940 questionnaires and collected 716 properly filled ones. Table 2 demonstrates details of sample distribution in various cities.

\section{Table 2}

The summary of sample distribution in various cities

\begin{tabular}{lcccc}
\hline City & Population & Percentage & Number & Valid \\
\hline Tehran & 8293140 & 44.46 & 410 & 382 \\
Karaj & 2024765 & 10.85 & 102 & 54 \\
Mashhad & 3069941 & 16.45 & 155 & 78 \\
Ahvaz & 1395184 & 7.47 & 71 & 56 \\
Esfahan & 2174172 & 11.69 & 109 & 60 \\
Tabriz & 1695094 & 9.08 & 93 & 86 \\
\hline Total & 18652296 & 100 & 940 & 716 \\
\hline
\end{tabular}

In order to validate the questionnaire, we first distribute the questionnaire among 31 university professors. Cronbach alpha has been calculated as 0.88 , which is well above the minimum acceptable level of 0.7. Therefore, we may distribute the questionnaire among the samples from the distribution. In addition, Table 2 demonstrates the summary of Kolmogorov-Smirnove as well as Shapiro-Wilk tests.

Table 2

The summary of Kolmogorov-Smirnove as well as Shapiro-Wilk tests

\begin{tabular}{lccccccc}
\hline \multicolumn{4}{c}{ Kolmogorov-Smirnov(a) } & \multicolumn{3}{c}{ Shapiro-Wilk } \\
\hline & Statistic & df & Sig. & Statistic & df & Sig. \\
\hline Distribution & .026 & 706 &. $\mathbf{2 0 0}$ & .996 & 706 & .05 & \\
\hline
\end{tabular}

Based on the results of Table 2, all components of the survey are normally distributed and we may use parametric tests to examine the hypotheses of the survey. In addition, Kaiser-Meyer-Olkin Measure of Sampling adequacy and Bartlett's test of Sphericity approximation Chi-Square are 0.878, 276628 with Sig. $=0.000$, respectively. The proposed study of this paper uses structural equation modeling to test different hypotheses of the survey. The Root Mean Square Error of Approximation 
(RMSEA), Comparative Fit Index (CFI) and Chi-Square/df are 0.067, 0.840 and 4.244 and they are within desirable levels.

\section{The results}

In this section, we present details of our findings on testing various hypotheses of the survey. Fig. 1 demonstrates the results of our findings.

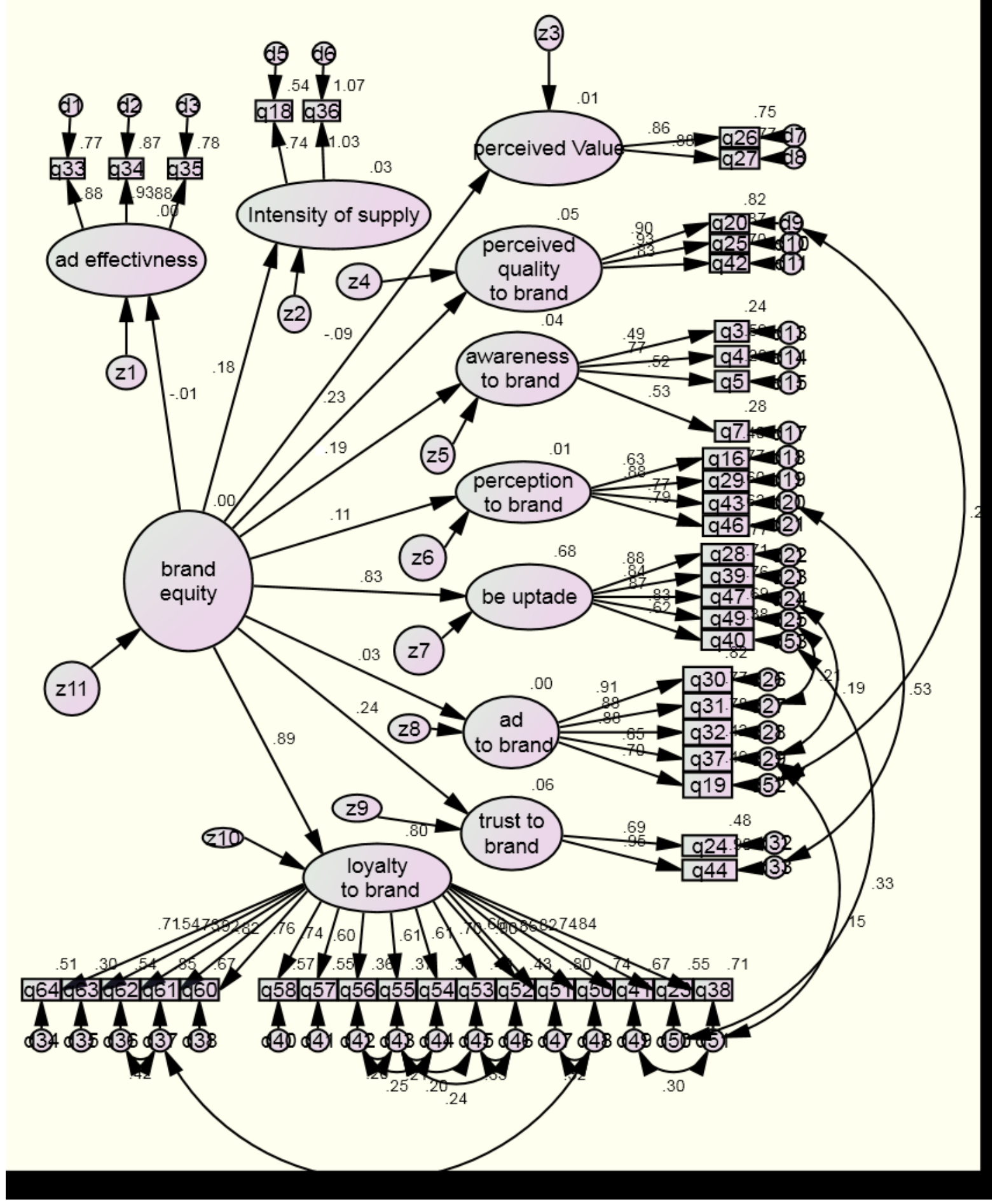

Fig. 1. The summary of standard coefficients of the implementation of structural equation modeling 
According to the results of Fig. 1 and by considering the corresponding t-student values, we may summarize the results of our survey on testing all ten hypotheses of the survey in Table 3 as follows,

Table 3

The summary of testing various hypotheses of the survey

\begin{tabular}{lcccc}
\hline Component & $\beta$ & Standard error & Critical value & Result \\
\hline Perceived Value & -.086 & .120 & -1.557 & Reject \\
Advertisement effectiveness & -.007 & .869 & -.165 & Reject \\
Brand loyalty & .894 & .014 & 2.452 & Confirmed \\
Trust to brand & .241 & .032 & 2.145 & Confirmed \\
Intensity of supply & .177 & 0.44 & 2.016 & Confirmed \\
Perception to brand & .112 & .006 & 2.766 & Confirmed \\
Brand awareness & .189 & .036 & 2.094 & Confirmed \\
Advertisement to brand & .034 & .441 & .771 & Reject \\
Be update & .827 & .011 & 2.538 & Confirmed \\
Perceived quality to brand & .231 & .021 & 2.316 & Confirmed \\
\hline
\end{tabular}

\section{Discussion and conclusion}

According to the results of Table 3, the effects of seven factors on brand equity have been confirmed. However, the survey does not confirm the effects of perceived value, advertisement effectiveness and advertisement to brand on brand equity. In our survey, brand loyalty maintains the highest positive impact followed by having updated brand, trust to brand, perceived quality to brand, brand awareness, intensity of supply and perception to brand. While the initial purchase of a product on the market may create some involvement, but repurchase the goods normally becomes a habit and a daily activity. This situation has led some scholars to believe that the purchasing decision process occurs less on the markets. However, when there are some changes on technological features of products, customers may rethink about the purchasing behavior based on decision methods.

Getting involved in purchasing decision is part of consumer's loyalty to product. Therefore, if there is any product development especially in design part of the products, customers may change their habits and rethink about purchasing the product. This survey has accomplished among Iranian consumers and these people normally get used to purchase an old fashion products and services. People may be more interested in purchasing a particular product when they have good memory on products and services. Therefore, brand owners must improve brand position by building a good image on customers' minds. In our survey, we have learned that most business owners concentrate more on sales than building brand. During the past few years, many Iranian people tend to watch more nonnational TV programs using Satellite broadcast programs. This makes advertisement more complicated for Iranian business owners since they are not permitted to place any sort of advertisement on such TV channels.

Access to brand is another important issue, which could influence buying opportunities. When a consumer cannot find his/her favorite brand on the shelf, he/she may switch to alternative ones. The findings of this survey recommend to producers to make sure about the availability of their products on different stores such as well-known chains.

The findings of this survey are consistent with earlier studies such as Motameni and Shahrokhi (1998), Netemeyer et al. (2004) and Yoo et al. (2000). Karbasi and Rad (2014) investigated the effect of sales promotions characteristics on brand equity. They examined the effectiveness of sale promotions on the brand equity of ETKA chain stores in Iran. They reported that monetary and nonmonetary promotions could influence on brand association, brand awareness and the perceived quality. On the other hand, they reported that brand association and the perceived quality were influential on brand loyalty. Pirayesh and Ghaempanah (2014) investigated the effects of multimedia 
advertising on building brand equity. In other words, the study has determined a positive and meaningful relationship between these two variables.

\section{Acknowledgement}

The authors would like to thank the anonymous referees for constructive comments on earlier version of this paper.

\section{References}

Aaker, D. A. (1992a). The value of brand equity. Journal of Business Strategy,13(4), 27-32.

Aaker, D. A. (1992b). Managing the most important assets: Brand equity. Strategy \& Leadership, 20(5), 56-58.

Aaker, D. A. (1996). Measuring brand equity across products and markets. California Management Review, 38(3), 103.

Aaker, J. L. (1997). Dimensions of brand personality. Journal of Marketing Research, 34(3), 347356.

Aaker, D. A. (2009). Managing brand equity. Simon and Schuster.

Aaker, D. (2012). Building strong brands. Simon and Schuster.

Agarwal, M. K., \& Rao, V. R. (1996). An empirical comparison of consumer-based measures of brand equity. Marketing Letters, 7(3), 237-247.

Aggarwal, P. (2004). The effects of brand relationship norms on consumer attitudes and behavior. Journal of Consumer Research, 31(1), 87-101.

Ambler, T., Kokkinaki, F., \& Puntoni, S. (2004). Assessing marketing performance: reasons for metrics selection. Journal of Marketing Management, 20(3-4), 475-498.

Ambler, T., \& Styles, C. (1997). Brand development versus new product development: toward a process model of extension decisions. Journal of Product \& Brand Management, 6(4), 222-234.

Anselmsson, J., Johansson, U., \& Persson, N. (2007). Understanding price premium for grocery products: a conceptual model of customer-based brand equity. Journal of Product \& Brand Management, 16(6), 401-414.

Atilgan, E., Aksoy, S., \& Akinci, S. (2005). Determinants of the brand equity: a verification approach in the beverage industry in Turkey. Marketing Intelligence \& Planning, 23(3), 237-248.

Atilgan, E., Akinci, S., Aksoy, S., \& Kaynak, E. (2009). Customer-based brand equity for global brands: A multinational approach. Journal of Euromarketing, 18(2), 115-132.

Baldauf, A., Cravens, K. S., \& Binder, G. (2003). Performance consequences of brand equity management: evidence from organizations in the value chain. Journal of Product \& Brand Management, 12(4), 220-236.

Chaudhuri, A., \& Holbrook, M. B. (2001). The chain of effects from brand trust and brand affect to brand performance: the role of brand loyalty. Journal of Marketing, 65(2), 81-93.

Farquhar, P. H. (1989). Managing brand equity. Marketing Research, 1(3), 24-33.

Fernández-Barcala, M., \& González-Díaz, M. (2006). Brand equity in the European fruit and vegetable sector: A transaction cost approach. International Journal of Research in Marketing, 23(1), 31-44.

Gil, R. B., Andrés, E. F., \& Salinas, E. M. (2007). Family as a source of consumer-based brand equity. Journal of Product \& Brand Management, 16(3), 188-199.

Grannell, C. (2009). Untangling Brand Equity, Value and Health. Brandchannel.

Karbasi, B \& Rad, A. (2014). The effect of sales promotions characteristics on brand equity. Management Science Letters, 4(9), 2107-2116.

Keller, K. L., Parameswaran, M. G., \& Jacob, I. (2011). Strategic brand management: Building, measuring, and managing brand equity. Pearson Education India.

Lassar, W., Mittal, B., \& Sharma, A. (1995). Measuring customer-based brand equity. Journal of Consumer Marketing, 12(4), 11-19. 
Motameni, R., \& Shahrokhi, M. (1998). Brand equity valuation: a global perspective. Journal of Product \& Brand Management, 7(4), 275-290.

Netemeyer, R. G., Krishnan, B., Pullig, C., Wang, G., Yagci, M., Dean, D., ... \& Wirth, F. (2004). Developing and validating measures of facets of customer-based brand equity. Journal of Business Research, 57(2), 209-224.

Pirayesh, R \& Ghaempanah, M. (2014). The effects of multimedia advertising on building brand equity. Management Science Letters, 4(8), 1761-1764.

Yoo, B., Donthu, N., \& Lee, S. (2000). An examination of selected marketing mix elements and brand equity. Journal of the Academy of Marketing Science, 28(2), 195-211. 